\title{
Local-foreign technology interface, resource-based development, and industrial policy: how Chile and Malaysia are escaping the middle-income trap
}

\author{
Amir Lebdioui ${ }^{1}$ (D) $\cdot$ Keun Lee ${ }^{2,3} \cdot$ Carlo Pietrobelli $^{4}$
}

Published online: 20 June 2020

(c) The Author(s) 2020

\begin{abstract}
This paper starts by showing that Chile and Malaysia are on the path of escaping the middle-income trap in terms of their income level relative to that of the USA. In contrast to the conventional view, we find that the leading export sectors are not manufacturing (such as electronics) in Malaysia or mining alone in Chile. Instead, the engines of growth have been (1) resource-based sectors (petroleum, rubber and palm oil) in Malaysia; and (2) nonmining resource-based sectors (salmon, fruits, wine and wood-based) in Chile. Furthermore, the sustained growth of these sectors is not the result of free-markets, as frequently argued, but also of specific industrial policy measures, that have enabled the accumulation of productive and innovation capabilities through R\&D support, fiscal incentives, export assistance, and quality control. We also find that the emergence of locally-controlled firms has been an important aspect of this long-term success, although the sources of the initial learning included foreign actors and FDI. The cases of Chile and Malaysia consequently show the possibility of escaping the middle-income trap not through manufacturing but instead through resource-based development. Such strategy differs from the so-called short cycle technology-based catch-up by the East Asian tigers and from the unsustainable commodity rent-extraction in resource-rich countries, but is consistent with the view that emphasizes the need to specialize in sectors with low entry barriers, and to promote investments in innovation and technological capabilities.
\end{abstract}

Keywords Resource-based development $\cdot$ Industrial policy $\cdot$ Chile $\cdot$ Malaysia $\cdot$ Middleincome trap $\cdot$ Salmon $\cdot$ Palm oil

JEL Classification $\mathrm{O} 25 \cdot \mathrm{O} 3 \cdot \mathrm{O} 4 \cdot \mathrm{O} 13 \cdot \mathrm{O} 14 \cdot \mathrm{O} 53 \cdot \mathrm{O} 54$

Earlier versions of this paper were presented in various conferences and seminars, including the European Association for Evolutionary Political Economy (EAEPE) 2019 annual conference held in Warsaw, Poland. We thank all attendees in the session, Nicholas Vonortas, and other guest editors for the useful comments. The second author acknowledges the partial funding by the Basic Research Program of the National Research University Higher School of Economics (HSE) and by the Russian Academic Excellence Project '5-100'.

Amir Lebdioui

a.a.lebdioui@1se.ac.uk

Extended author information available on the last page of the article 


\section{Introduction}

The so-called middle-income trap (MIT) refers to a situation where middle-income economies tend to face a decelerated growth and consequently fail to join the rank of high-income economies. According to World Bank (2012:12), a country can be considered in the MIT if its per capita income remains in the 20 to $40 \%$ range of the US per capita income for several decades. While the majority of middle-income economies are still in this trap, the East Asian tigers (South Korea, Taiwan Hong Kong and Singapore) are amongst some of the few examples of countries that have escaped this trap. Nevertheless, recently, there are some signs that Malaysia and Chile are also overcoming the MIT, as both economies have reached more than $40 \%$ of the level of US per capita income. This paper explains how both countries have been able to escape the trap by investigating which sectors are leading their growth and exports in particular, and how policies helped in this regard.

The cases of Chile and Malaysia can shed a new light on the debate relating to the middle-income trap and economic growth in the latecomer economies. If Malaysia is escaping the MIT, it raises the puzzle of how it has achieved such performance despite its perceived failure in automotive industry and mixed success in the electronics industry (Cherif and Hasanov 2019a; Rasiah 2006; Yusuf and Nabeshima 2009). Chile is also an interesting case because it has been a symbol of so-called neo-liberalism in Latin America as it followed the free-market oriented Washington Consensus for many years (Williamson 1990), which was perceived largely as a failure (Rodrik 2006). In fact, several scholars have praised Chile for its success through its free market approach (Barro 2000; Valenzuela and Dammert 2006), and even Stiglitz (2002) considered Chile as an exceptional success despite the unregulated free market-oriented policy regime. So, the question is whether Chile's growth is owing to its liberal policies or something else.

In this paper we argue that governments in both economies have succeeded through active industrial policy interventions to promote not manufacturing but several leading resource-based sectors, such as petroleum, rubber and palm oil sectors in Malaysia, and salmon, fruits, wine and forestry in Chile. In Malaysia, these resource-based industries have shown great degrees of linkage development, competitiveness and technological sophistication, notably through governmental support for R\&D activities, in contrast to the weak performances of the Malaysian electrical and electronics (E\&E) and automotive sectors. In Chile, the successful emergence of competitive export industries since the $1960 \mathrm{~s}$ has helped sustain growth beyond the copper sector, and we show that this has been related to long-term policies building local capabilities in production and innovation through both vertical and horizontal interventions.

The next section discusses the literature analysing the MIT and lays out the theoretical framework we follow in the paper. Then, Sect. 3 provides evidence that Chile and Malaysia are on the path to escaping the MIT, mainly through exports of new leading sectors, which tend to be all resource-based, and different from the traditional leading sectors. The fourth and fifth sections investigate the underlying mechanisms for building local capabilities in production and innovation and for managing the local-foreign interface in the leading resource-based sectors in both countries. The concluding section summarizes the findings of this study. 


\section{The middle-income trap and our theoretical framework}

The existence of a 'middle income trap' (MIT) was first mentioned by Gill and Kharas (2007) and has since gained popularity amongst scholars and international institutions (e.g. Cherif and Hasanov 2019a, b; Eichengreen et al. 2012, 2013; Ito 2017; Lee 2013; World Bank 2010). However, some scholars have rejected the existence of this trap on the ground that there is no reason to believe that middle-income economies adopt different growth mechanisms (e.g. Aiyar et al. 2013; Han and Wei 2017; Im and Rosenblatt 2013). The debate and conflicting views over the past decade regarding the existence of the MIT are due to the differences in definitions of the trap and different methodologies to test its existence (Lee 2019). Regardless of its existence, it is clear that many middle-income economies are struggling to achieve high-income status, and it is therefore a relevant issue. ${ }^{1}$

Diverse studies have tried to investigate the key factors responsible for the MIT, such as demographic conditions, institutions, industry and trade structures, diversification, physical infrastructure, and macro-financial developments (Aiyar et al. 2013). One argument, supported by the ADB-sponsored study of Eichengreen et al. (2012, 2013) and Lee (2013), is that innovation capabilities are the key binding constraint for the MIT. This view is also consistent with the early statement by the World Bank that middle-income economies would tend to fall under a trap because they get caught between low-wage manufacturers and high-wage innovators; their wage rates are too high to compete with low-wage exporters and the level of their technological capability is too low to enable them to compete with advanced countries (World Bank 2010). The importance of innovation as the cause of the MIT is also consistent with the experience of a very small number of East Asian economies that successfully transitioned into high-income economies in the past decades. These include South Korea and Taiwan that, since the mid-1980 s, due to their growing innovation capabilities, made a transition from low-wage based to high-end goods economy (Lee 2013; Ch. 3).

If one asks who creates and promotes such innovation capabilities, the answer from East Asia is that they are locally-controlled companies, and many of them have initially learned from foreign MNCs or through the OEM (Original Equipment Manufacturing) arrangements with MNCs. Amsden (1989) is one of the early studies that emphasizes the importance of promoting local ownership rather than passive reliance on Foreign Direct Investment (FDI). The success of Taiwanese catch-up is also supported by the eventual rise of indigenous firms (Amsden and Chu 2003, Guerrieri et al. 2001). A similar view is shared by Marin and Bell (2006), who observe that the spillover effects of FDI does not occur if host countries do not focus on the linkages between FDI and the domestic economy. Lee et al. (2016) and Lee and Lim (2001) observe that FDI can be an important channel for gaining foreign knowledge, but tends to interfere with the eventual growth of indigenous technological capabilities. ${ }^{2}$ Then, indigenous ownership becomes more important at

\footnotetext{
1 A study by the World Bank (2012: 12) finds that only 12 out of 101 middle-income economies have reached the status of high-income economy since 1960.

2 These remarks are based on comparable examples in the automotive sectors of China and Korea (e.g., Geely and Chery vs. Shanghai Volkswagen and First Auto Works in China, and Hyundai Motors vs. GMDaewoo in Korea).
} 
later stage, because foreign firms tend to become increasingly reluctant to transfer or sell technology. ${ }^{3}$

For latecomers, participating in global value chains (GVC) offers opportunities to access export markets by specializing in specific segments, with a hope to gradually upgrade into high-end segments. Relatedly, Lee et al. (2018) introduced the "In-Out-In Again" pattern in terms of the changing degree of participation in GVCs. The idea was that at the initial stage of growth by a latecomer, increased participation in GVC is necessary to learn foreign knowledge and production skills. In the effort to functionally upgrade at the middle-income stage, countries must seek separation and independence from existing foreigndominated GVCs to increase domestic value-added. Finally, after establishing their local value chains, latecomer firms and economies may have to seek reintegration into the GVC, often leading the chains themselves. However, this is only one of the many possible ways GVCs and their governance coevolve with innovation systems (Lema et al. 2019). In fact, many countries remain stuck in low-value-added activities along the GVC, if they do not exert the necessary complementary efforts to develop technologies and capabilities (Morrison et al. 2008).

Creating and strengthening technological capabilities has often not been easy in emerging economies, due to the presence of not only market failures but also system and learning failures (Lee 2019: 40; Table 2.1). The existence of such failures justifies public interventions to provide opportunities to learn and develop technological capabilities, often in diverse private-public collaborative modes, with the engagement of public research organizations. However, such interventions require careful assessment of their costs and benefits.

One important criterion to consider for policy interventions relates to the magnitude of entry barriers for newcomers. In this paper, we argue that resource-based sectors tend to be associated with lower entry barriers than most manufacturing sectors, depending upon natural endowment and historical legacies. Thus, resource-based sectors would be an alternative to short-cycle manufacturing or services (e.g. IT), meeting the criterion of low entry barriers for latecomers. ${ }^{4}$ Figure 1 summarizes the above discussion, as it explains that the MIT is caused by weak innovation capabilities, which requires public intervention or industrial policy to overcome due to several market failures; and that such interventions can lead to successful outcomes only when they lead to the eventual growth of indigenous firms in certain sectors with low entry barrier in terms of international competition.

In addition to the short-cycle technology-based catch up in manufacturing or services, and the resource-based development pathway discussed here, Fig. 1 also indicates another escape route from the MIT, that is not analysed in detail here, but that may prove useful to make our point regarding our country cases. This route is typically followed by countries with high commodity rents per capita, such as Qatar, Kuwait, UAE, or Equatorial Guinea, whose economic model is not really sustainable in the long term as it is highly vulnerable to commodity price fluctuations, and reversible. ${ }^{5}$ Moreover, most oil exporters have recorded poor productivity growth and witnessed relative income decline compared to the

\footnotetext{
3 An example was observed in Korea when Korean IC chip firms caught up with foreign firms, and the latter became increasingly reluctant to provide designs for chip production (Kim 1997, Lee and Lim 2001).

${ }^{4}$ Lee (2019) points out that at the middle-income stages, Korea and Taiwan went through a different path by specializing in sectors with "short-cycle" technologies (Lee 2013), which can be considered as low entry barrier sectors in that technologies dominated by incumbents tend to be disrupted radically and frequently.

5 See the example of Nauru, a country with the highest GDP per capita in the world in the $1970 \mathrm{~s}$ due to the rents generated by the sale of phosphate of more than USD 27,000 per capita, that fell back dramatically after the exhaustion of their deposits (Trumbull 1982).
} 


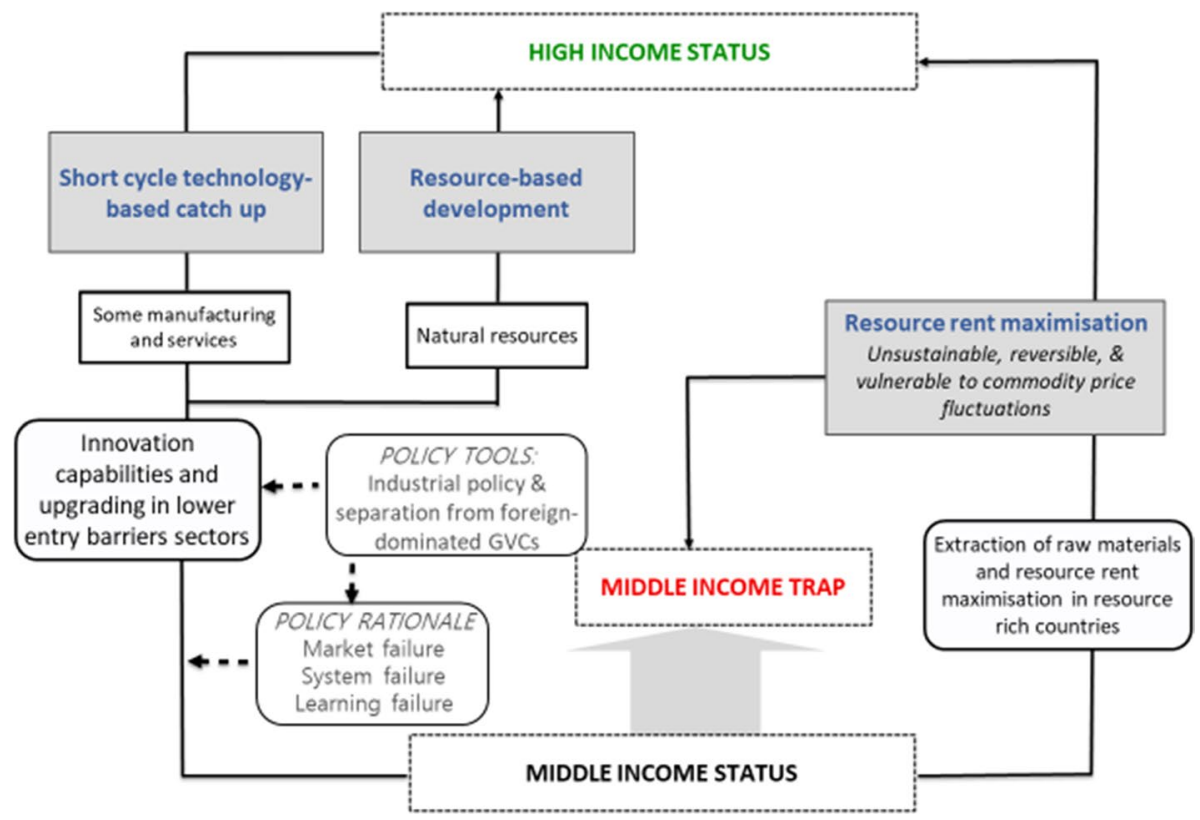

Fig. 1 Possible Transitions from Middle-Income Traps. Source: Authors' elaboration

United States over the last 30 years (Cherif et al. 2016). Such 'resource rents extractionbased' development model remarkably differs from the resource-based development pathways of Chile and Malaysia analysed in this paper, which focuses to larger extent on the development of upstream and downstream linkages around commodity extraction, and on the development of new resource-based activities with considerable knowledge and technological spillovers. Importantly, this distinction echoes Schumpeter's (1943) difference between the rents created through innovation and those by statically maximising profits by appropriating higher rents from existing resources. Taking the above discussion further, in Sects. 4 and 5 we investigate the cases of Chile and Malaysia.

\section{Growth beyond the middle-income trap and leading sectors}

\subsection{Growth beyond the MIT}

This section evidences that Chile and Malaysia appear to have recently achieved- or are close to transitioning towards- a high-income status. First, Fig. 2 suggests that Chile and Malaysia, unlike most other middle-income countries, such as Brazil, Mexico, Egypt, or Algeria, have been growing at faster rates in the past decades. In 1990, the per capita income levels of these two countries were similar to to Brazil and Algeria but lower than Mexico. By 2017, these two economies surpassed Mexico, and reached the level of USD 23,000 or higher, which is far ahead of Brazil or Algeria, below USD 15,000.

One way the literature has determined whether a country is beyond the middleincome trap is by measuring a country's relative income level to the USA. According 


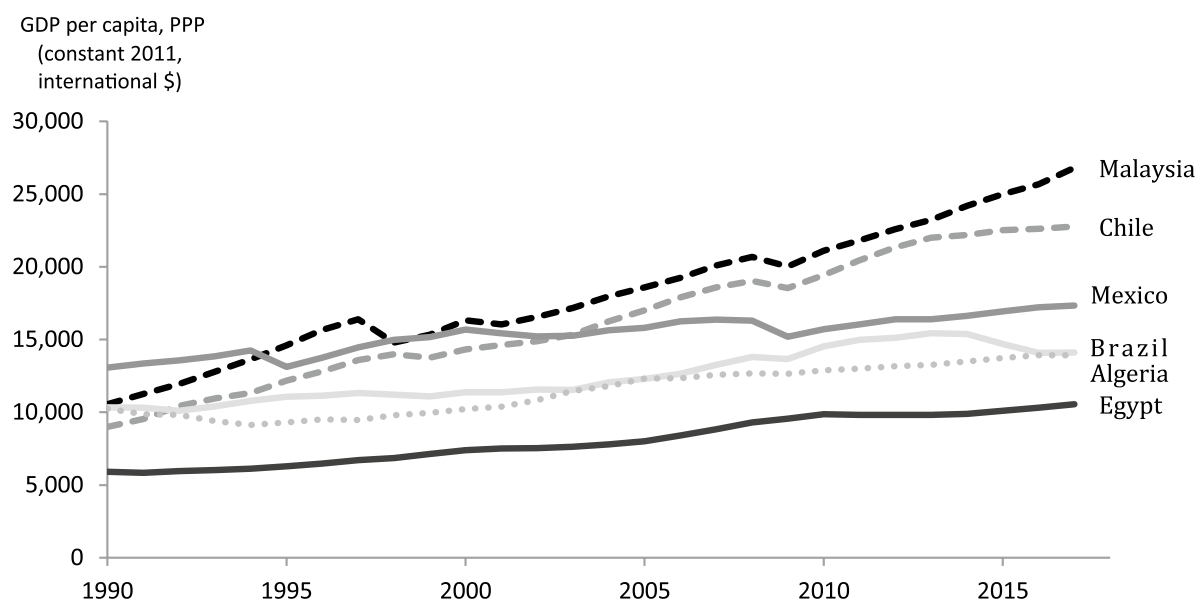

Fig. 2 GDP per capita in selected countries. Source: World Bank, World Development Indicators (2018)

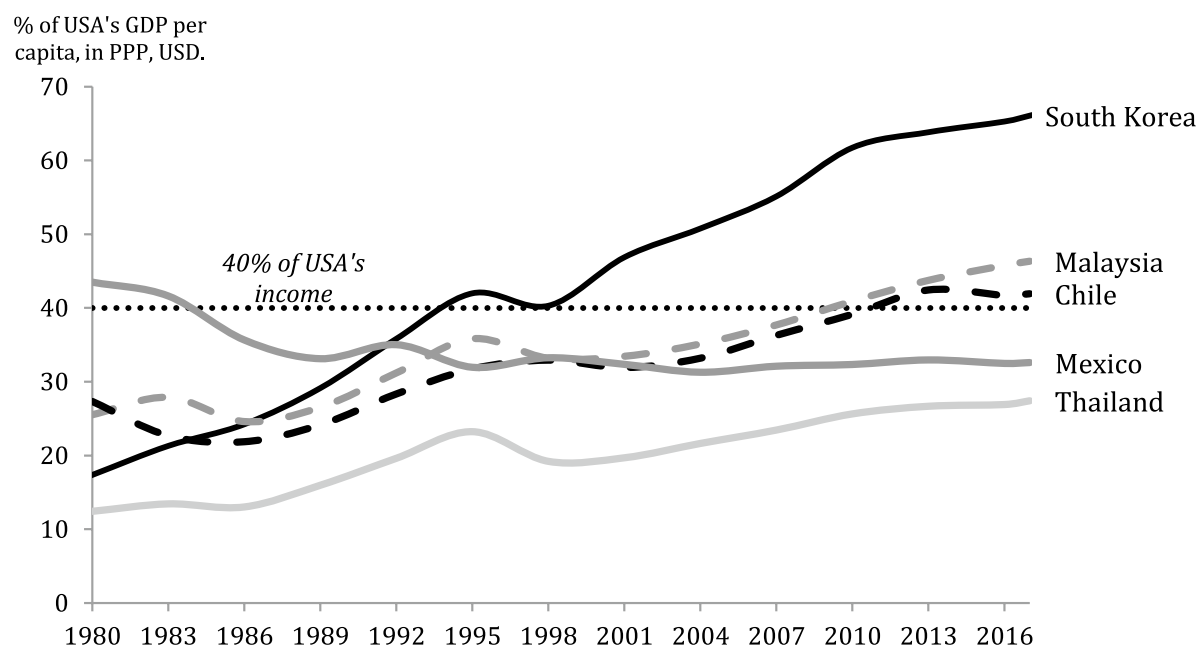

Fig. 3 GDP per capita as \% of US GDP per capita in selected countries. Source: Drawn by the authors using the data from International Monetary Fund (2017)

to the World Bank (2012: 12), a country can be considered in the trap if its per capita income remains in the 20 to $40 \%$ range of the US per capita income for several decades. The same study shows that only 13 economies escaped the trap during 1960-2008. Our calculations show that both Malaysia and Chile have escaped the MIT since the $2010 \mathrm{~s}$ (IMF data). In 2017, Malaysia and Chile respectively reached $46.3 \%$ and $41.9 \%$ of US income (Fig. 3). Most emerging economies have not closed the gap with the USA, remaining below the $40 \%$ threshold. Mexico's GDP per capita declined from above $40 \%$ in the mid-1980 s to $32.8 \%$ of the US' GDP in 2015. Brazil and South Africa's GDP per capita have also dropped to below $30 \%$ since the $1980 \mathrm{~s}$. 


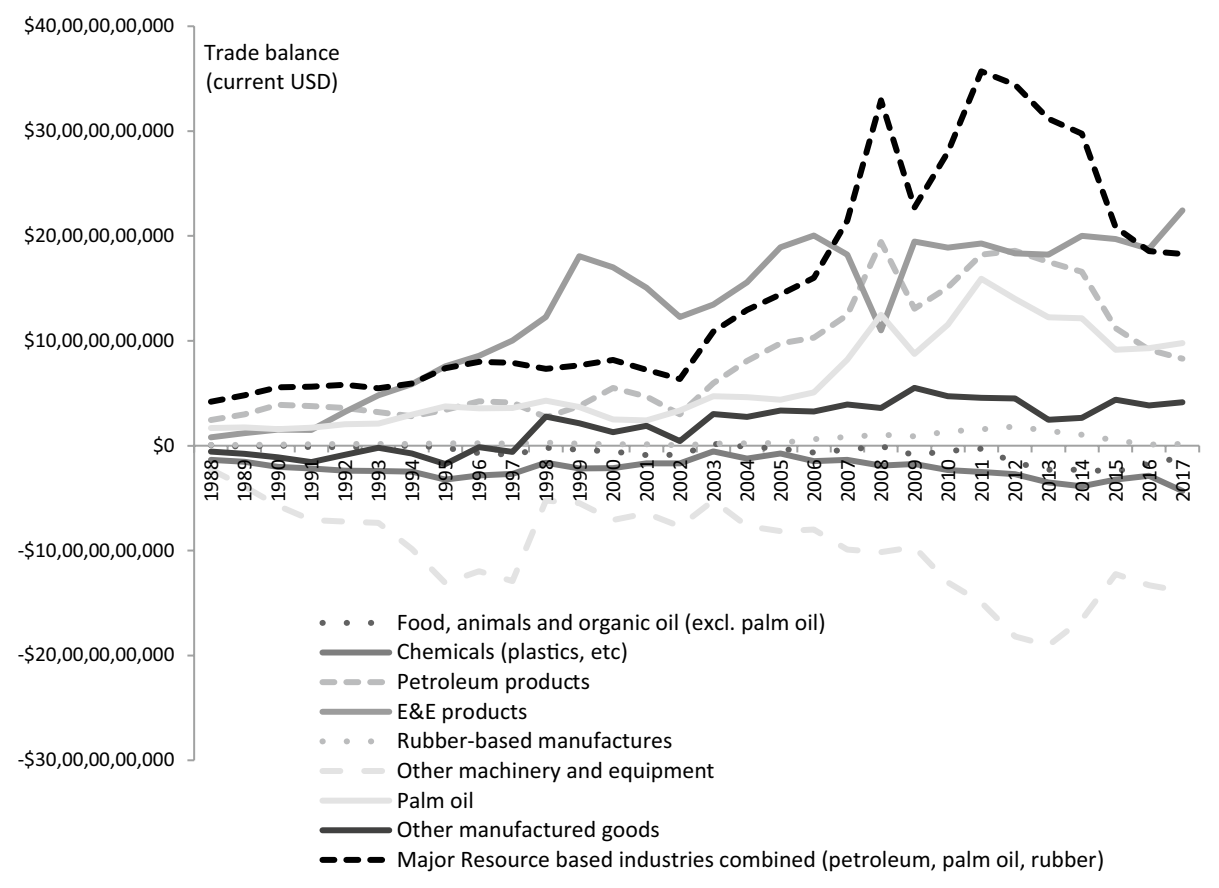

Fig. 4 Malaysia: trade balance by sector (1988-2017). Source: Authors' compilation based on data provided by UN Comtrade Database

\subsection{The leading sectors in Malaysia and Chile}

This subsection compares the export performance of the resource-based sectors with 'traditional' leading sectors in Chile and Malaysia. We focus on export performance, as developing countries must earn hard currencies through exporting to pay for the imported capital goods that are required for investments and sustained economic growth (Ramanayake and Lee 2019).

Resource-based industries have been an engine of exports in both Chile and Malaysia. In Chile the combined export share of new resource-based industries (the salmon, wine, fruit and wood-based industries) ${ }^{6}$ has reached $28 \%$ by 2017 , becoming the second largest contributor to exports after mining (55\%). ${ }^{7}$ In Malaysia the combined export share of resource-based industries (petroleum, palm oil and rubber) reached $21 \%$ in 2017, following the E\&E sector, which represents an export share of $38 \%$.

More importantly, these sectors are contributing to large and increasing trade surpluses. Figure 4 shows that the combined trade surplus of the key resource sectors in Malaysia has even become larger than that of the E\&E sector since 2007. In contrast, the contribution of the latter has been mostly stagnant since 2000. Figure 5 shows that the contribution of mining in Chile peaked in 2011 and declined since then, whereas

\footnotetext{
6 Wood-based products here correspond to the sum of products with the following SITC3 codes: $63,64,24$ and 25. Wood-based sector and forestry sector are used interchangeably in this paper.

7 These figures are all from UN Comtrade Database.
} 


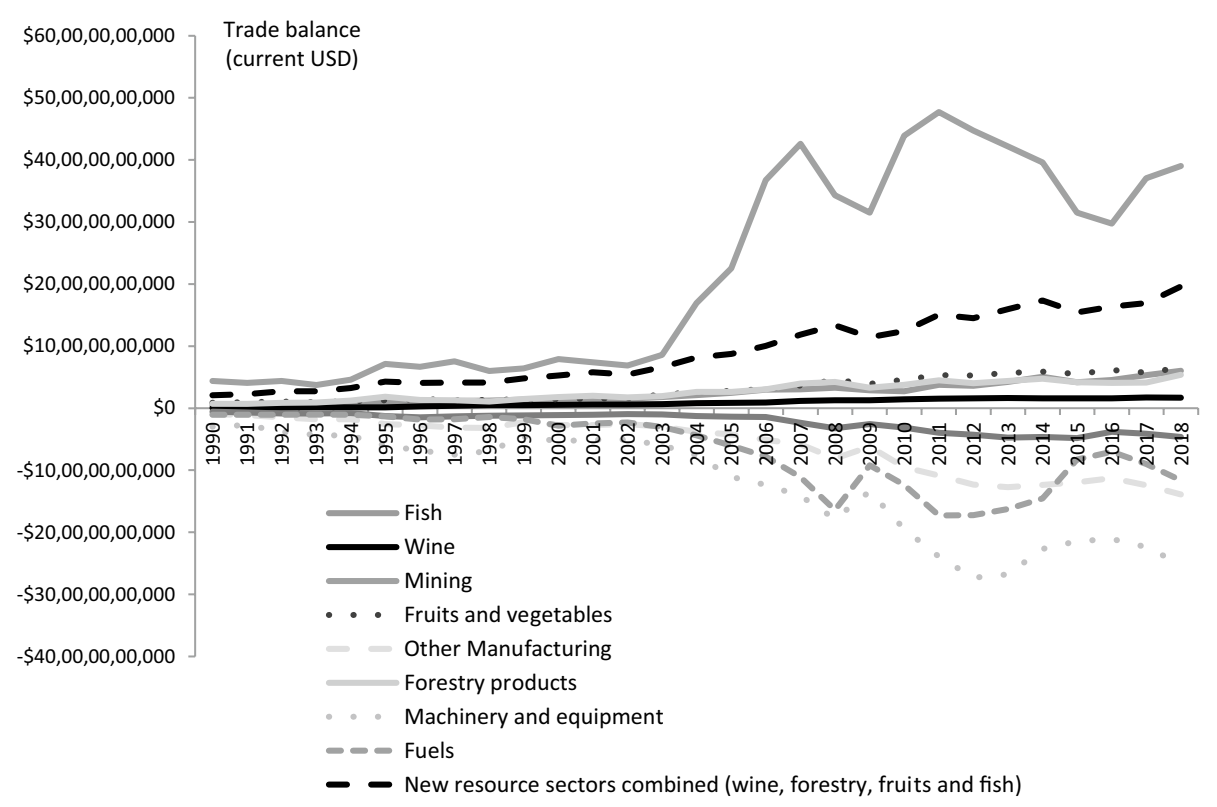

Fig. 5 Chile: trade balance by sector (1990-2018). Source: Authors' compilation based on data provided by UN Comtrade Database

the combined share of key resources has been steadily increasing, reaching almost half of the amount of mining. In contrast, machinery \& equipment and other manufacturing sectors have recorded ever-increasing deficits.

These results are consistent with the revealed comparative advantages of selected sectors of the two countries (See "Appendix" Figs. 8 and 9). RCA values larger than one indicate that that product of that country is internationally competitive, which is for the cases of resource sectors of Chile, such as wine, fish, fruits and wood-based products, with higher than 6 since 1995. RCA values in key resource sectors of Malaysia are also high, such as palm oil products (30 or higher), rubber and fuels (higher than 1), whereas the automobile sector corresponds to RCA values always less than 0.2 throughout the period.

However, are these resource-based exports mainly unprocessed resources, generating little domestic value-added? We have some insightful details for Malaysia. Figures 6 and 7 show that a progressive downstream value addition has taken place in the exports of these three sectors since the $1960 \mathrm{~s}$. The share of crude rubber and crude petroleum has both decreased from over $90 \%$ in 1960 to less than $30 \%$ in 2010 s (Fig. 6). In contrast, the share of rubber-based manufactured products increased to over $50 \%$ of total rubber exports by 2012 , while the share of petroleum-based products increased from less than $10 \%$ to over $70 \%$ of petroleum products by 2014 . The same evidence for processed palm oil exports is shown in Fig. 7. Transition from exporting crude to processed palm oil is a distinctive achievement of Malaysia, which did not happen in Indonesia in the same period (Sato 2016).

With regard to Chile, the new resource sectors are highly sophisticated and technologyintensive. For example, salmon production requires technologies, such as cold storage systems, vaccines, and the transportation of fresh products to distant geographical markets 

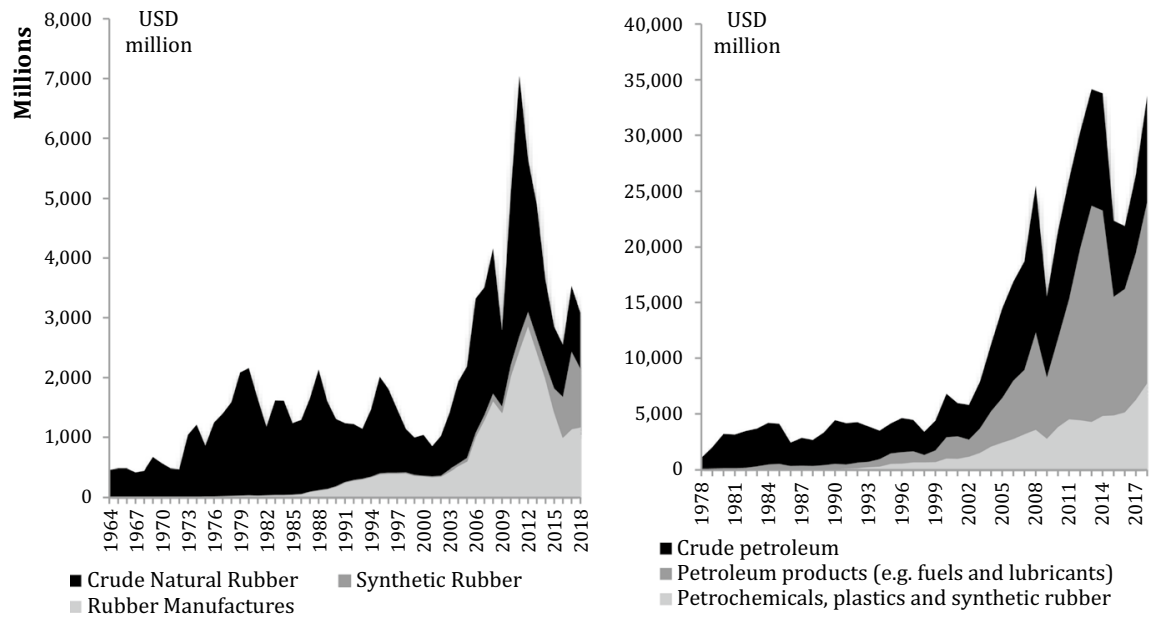

- Crude petroleum

Petroleum products (e.g. fuels and lubricants)

$\square$ Petrochemicals, plastics and synthetic rubber

Fig. 6 Malaysia. Evolution of the composition of rubber and petroleum industries' exports 1964-2018. Source: UN Comtrade (2019)
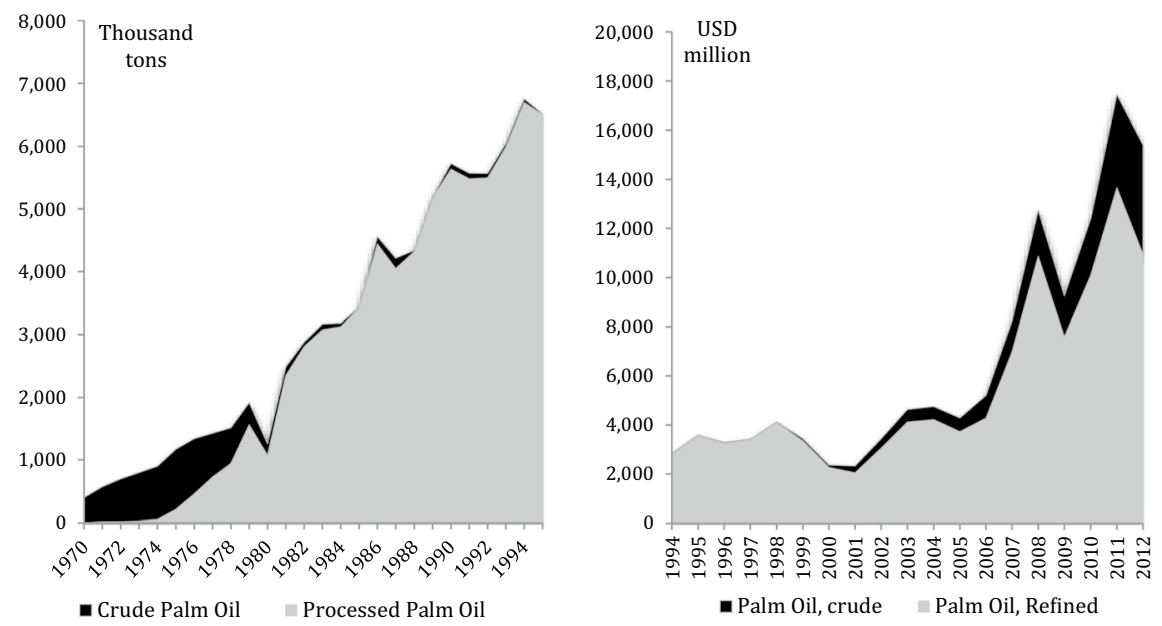

Fig. 7 Composition of Malaysia's palm oil exports, 1960-94 based on export volume (left); and 1994--012 based on export values (right). Source: Gopal (2001); UN Comtrade (2019) 
(Lebdioui 2019c). Wood-based products also include diverse kinds of value-added products, such as pulp, paper, paperboard, cork, and furniture.

\section{Industrial policy and upgrading in key sectors of Chile}

Over the last five decades, Chile has experienced an interesting (but uneven) process of upgrading and capability building at the sector level. Some sectors, such as wine and salmon, have become increasingly technology-intensive, with significant R\&D activity, growing importance in world markets, and high levels of cooperation between firms and research institutions (Benavente and Goya 2012). For instance, firms in the salmon sector have gradually closed the technological gap with frontier capabilities (Iizuka et al. 2016). In contrast, most mining suppliers still classify as displaying average or low capacity in production management and adaptation of available technologies, while no local mining supplier is yet operating at the knowledge frontier (Bravo-Ortega and Muñoz 2015). The next two sections examine more closely the key sectors that have acted as an engine of growth in Chile in the past five decades.

\subsection{New resource sectors: salmon, fruits, wood-based products and wine}

Despite the predominance of copper in Chile's export basket, still over 50\% of total exports in 2017, Chile has undergone a process of export diversification since the $1960 \mathrm{~s}$, spurred by the emergence of new globally competitive tradable sectors such as salmon, fruits, wine and wood-based sectors. Chile's diversification strategy has focused on the identification of niche areas with potential for comparative advantage. However, as further argued below, this has not only been the result of free-market processes, but it has been achieved as a result of sector-specific initiatives for long-term investments and capability building, which we may call broadly industrial policy, both of a vertical and horizontal nature (Lebdioui 2019c). As discussed below, vertical interventions were more prominent in salmon, fruits and forestry, whereas the wine sector featured mostly horizontal interventions.

Chile's salmon, fresh fruits, wine and wood-based industries offer remarkable examples of key interventions of the state that fostered their initial development, always in the framework of an open market economy. In each of these sectors, there were key public actors that fostered its initial development (Lebdioui 2019c). In the case of the wood-based sector, since the 1960 s CORFO (Production Development Corporation of Chile) subsidized investments in planting of pino radiata, a non-native tree (CEPAL 1986, Pietrobelli 1993). ${ }^{8}$ For salmon harvesting technologies and the introduction of new fruit varieties, such as berries, the role of the public-private Fundación Chile was central (Pietrobelli 1998). Another essential feature of these nascent industries was the integration and adaptation of imported knowledge and technologies with local knowledge. What follows is an elaboration for each sector.

\footnotetext{
${ }^{8}$ CORFO was created following the earthquake that struck Chile in 1939 to reconstruct the country's industrial base through energy, mining, fishing, agriculture and infrastructure projects. In 2015, the financial support deployed by CORFO amounted to around USD 3 billion, which represents 1\% of Chile's GDP (Griffith-Jones et al. 2018).
} 
The wood-based sector is the sector that the Chilean government targeted most explicitly since the 1960 s (Pietrobelli 1998). At the time, the government made "a strategic bet on a non-existent but potentially profitable sector with latent comparative advantage" as it was known that radiata pine grew faster in certain parts of Chile than the rest of the world (Agosin et al. 2010:7). Thus, since the 1960 s CORFO subsidized investments in planting pino radiata (CEPAL 1986, Pietrobelli 1993). Technological and industrial upgrading subsequently followed owing not only to these subsidies but also to explicit promotion measures, such as bans on exports of raw wood and debarked logs, as well as the attraction of investments from leading producers of wood fiber and wood-based products (Rossi 1995; Lebdioui 2019c). So, there was a strong flow of FDI, especially from New Zealand, often in alliances with domestic companies already established within the sector. Since then, locally owned firms flourished, possibly owing to subsidized credits by the central bank through Decreto Ley $701 \& 2565$, and local initiatives for R\&D were met by the Forestry Institute. Decreto Ley 701, passed in 1974, granted cash subsidies of $75 \%$ of the costs of planting and the initial management of forests (Decreto Ley 2565 increasing the subsidy to 90\%). Public expenditures through subsidies and grants in the 20 years of application of the law Decreto Ley 701 amounted to USD 135 million. Total wood-based exports consequently rose from USD 127 million in 1974 (year of enactment of the Decreto Ley 701) to USD 1.5 billion in 1994, when the terms of the law ended (Rossi 1995). Nowadays, wood-based exports constitute Chile's fourth largest export item, with $9 \%$ of the total.

In both the salmon and fresh fruit industry, the comparative advantage Chile developed was not natural, but instead was acquired through the accumulation of human capital, technology and learning combined with favourable natural endowments. Both industries emerged as a result of technology transfer programs at the governmental level (through the Japan Chile Salmon project and the Chile-California programme to train agriculture engineers). Fundación Chile (FCh) has also played a key role in the experimentation into new activities with latent comparative advantage, developing pioneers and then promoting them as examples to follow through technology diffusion. Indeed, FCh's mandate as a notfor-profit semi-public agency enabled to treat R\&D and technology as "public goods" to be widely diffused amongst local entrepreneurs, in order to stimulate emulation and reduce entry barriers in new industries. This role has strongly encouraged Chile's upgrading in the salmon and fruits sectors through the creation of 'display' firms, such as Salmones Antartica in the salmon sector and Berries La Unión in the fruit sector.

Besides FCh, there are also public research units in charge of R\&D, such as Institute of Agricultural Research (INIA) in fruits, and Fisheries Development Institute and Fisheries Development Fund in the salmon sector. These public R\&D agencies have been instrumental in enhancing the capabilities of local firms to start developing their own technologies to meet their unique challenges and environment (Hosono 2010, 2016; Iizuka and Gebreeyesus 2012). Indeed, evidence reveals that Chile has registered many patents for salmon vaccines, bio-testing, and developed quality control labs, alongside salmon farming (Hosono 2010).

The wine sector in Chile has a long history, and thus its strong export growth in recent periods can be considered as an instance of export 'discovery' favoured by foreign direct investment (FDI), rather than a case of product discovery, as in the cases of the salmon and fruits sectors (Agosín and Bravo-Ortega 2009). Interestingly, in the wine sector, the role of the state was also important but mostly through horizontal policies (Giuliani et al. 2011). While some degrees of vertical interventions occurred through the Servicio Agricola Ganadero (SAG), which is in charge of quality inspection, horizontal interventions 
mostly relied on CORFO and Pro-Chile (export promotion agency offering export credit and financing), besides the national initiatives of free trade agreements (e.g. the one with South Korea, which has become an important importer of Chilean wine as a result). They are horizontal as they were equally helping all sectors. For instance, the role of ProChile was also critical for fresh fruit exports.

In the absence of a state agency providing vertical help in innovation and upgrading, it was mostly FDI that helped the wine sector to emerge and upgrade its technology. Foreign investors, especially from Spain, enabled knowledge transfer related to functions like grape growing, wine making and wine marketing. This favoured access to distribution channels in the major markets and the improvement of the Chilean wine image (Björk 2005; Kunc 2007; Kunc and Bas 2009). Overall, the wine industry constantly relied on flows of foreign oenologists and technology experts (Giuliani et al. 2011) as well as companies. As explained in Agosín and Bravo-Ortega (2009), Innovation in the Chilean wine industry has been enabled by "learning by looking" through several ways, including the participation of foreign oenologists in the Chilean harvest season, but also in the foreign travel of Chilean oenologists and viticulturists to the international centers of winemaking (sometimes at the charge of government development agencies). However, it is important to note that, in the wine sector, many locally-controlled firms have eventually grown to become the dominant form of firm ownership in the sector. For instance, in 2004, only 40 out a total of 265 vineyards in Chile had some degree of foreign equity in their ownership structure, producing around $15 \%$ of the total value of Chile's wine exports (Bustos et al. 2007). By the $2010 \mathrm{~s}$, over 200 globally competitive Chilean-owned firms had emerged in the wine sector, with above USD 1 billion exports (Gwynne 2012).

In sum, public institutions and industrial policy have been key in the process of capabilities accumulation that shaped the emergence of these new industries in Chile. This took the form of R\&D support, funding for technical training and human capital accumulation, regulatory and quality control for export markets, trade promotion, and technology diffusion, depending on each sector. These policies were often conceived as 'vertical' policies, explicitly targeting a sector. At other times, policies were designed to be horizontal, but given the country's productive specialization, also turned out to be vertical.

\subsection{Mixed success in the leading copper sector}

While the copper sector has accounted for more than half of Chile's total exports for the past decade, lower commodity prices have increased the vulnerability of the sector and have led to the decline of its trade surplus during 2011-2015 as shown in Fig. 5. While copper mining has represented the backbone of the Chilean economy, the efforts to diversify vertically and upgrade have largely failed, as explained below. More worryingly, in contrast to the salmon sector for instance, Chile has not managed to develop large-scale knowledge intensive activities around copper extraction. In view of the strong emergence of new resource sectors, the mixed success of copper mining can be attributed to the lack of an explicit industrial policy.

There are several cases of local suppliers that successfully transitioned as top tier suppliers in knowledge intensive services, (such as Neptuno Pumps, producing water pumps; ENAEX, producing blasting devices; DRILCO, producing drilling tools; and AguaMarina, producing bio-mining equipment) (Bravo-Ortega and Muñoz 2015; Pietrobelli et al. 2018; Lebdioui 2019a). These firms display high technological capabilities, international competitiveness, as well as the accumulation of transversal capabilities useful for other sectors. 
However, around $97 \%$ of mining suppliers still classify as displaying average or low capacity in the use of technology, mainly through production management or adaptation of available technologies, while very few local suppliers operate at the knowledge frontier (BravoOrtega and Muñoz 2015). Consequently, although the participation of Chilean mining suppliers has been increasing (and doubled since 2007), the level of exports, technological sophistication and knowledge intensity of supplies of goods and services around mining remain quite far from the levels reached in advanced resource-rich countries such as Australia. As Bravo-Ortega and Muñoz (2015) and Pietrobelli et al. (2018) explain, most local suppliers operate in a context of very marginal improvements in production management and adaptations of available technologies, without any major technological improvements.

The weak growth of locally-owned firms has to do with the absence of explicit industrial policies providing incentives for local suppliers to innovate, as well as high level of competition from foreign suppliers, which constitutes an entry barrier and a disincentive for local suppliers' upgrading and innovation (Pietrobelli et al. 2018). Most notably, the governance of the mining GVCs, in spite of a recent trend towards outsourcing, remains extremely hierarchical, with a strong preference for incumbent suppliers, and with the lead firms' persisting attitude to avoid the risks related to the search for local technological solutions on their suppliers (Pietrobelli et al. 2018, Stubrin 2018, Lebdioui 2019a; Iizuka et al. 2020). Given this situation, a poor matching prevails between mining MNCs and the solutions developed by local suppliers (e.g. Bravo-Ortega and Muñoz 2015; Urzúa 2017; Lebdioui 2019a).

In sum, public incentives for innovation, and support for skilled human capital accumulation have been largely lacking. There was no correction for capital market failures either. Although Chile's banking system is highly developed, there seems to be a lack of complementarity between the financing sector and the needs of mining suppliers. ${ }^{9}$

Further, the mining sector lacks a state agency that would foster R\&D, education and training, such as those in new resource sectors described above. Local universities do not contribute to the industry to a large extent (Confraria and Vargas 2019), and rarely offer human capital formation related to the fields of development of local providers (BravoOrtega and Muñoz 2015). ${ }^{10}$ Moreover, R\&D expenditures and researchers involved in the Chilean mining industry show a significant lag with respect to countries like Australia (Meller and Parodi 2017).

There have been recent efforts to address obstacles to the promotion of local suppliers. Some of these efforts were initiated by the multinational company BHP Billiton (later joined by the state-owned mining company Codelco), to create the so-called World-Class Supplier program in 2008. The program's primary objective was to promote the technological development of knowledge-intensive mining suppliers (KIMS) through increasing the demand for innovations, thereby solving coordination failures, and promoting internationalization. ${ }^{11}$ The results of the program are only partially positive, given that addressing

\footnotetext{
9 "It is not just about the financing but also about the knowledge on the process of scaling up: where to manufacture, how to package, in what quantities, at which prices, and where to outsource? [...] This is a challenge for small firms" (CEO of Aguamarina, cited in Lebdioui, 2019a).

10 Even Becas Chile, the government's scholarship program, does not discriminate in favor of specific strategic areas, which has resulted in the lack of human capital accumulation in engineering (OECD and World Bank, 2011).

11 The program works as follows (for details see Iizuka et al. 2020, and Navarro, 2018). The mining companies participating in the program identify a list of operational problems that a subcontractor could solve, and upload them on a website, managed by Fundación Chile. Selected companies are then invited to apply. Mining companies are expected to provide finally selected suppliers with access to facilities and non-pecuniary resources like technical assistance on production and commercialization during project development.
} 


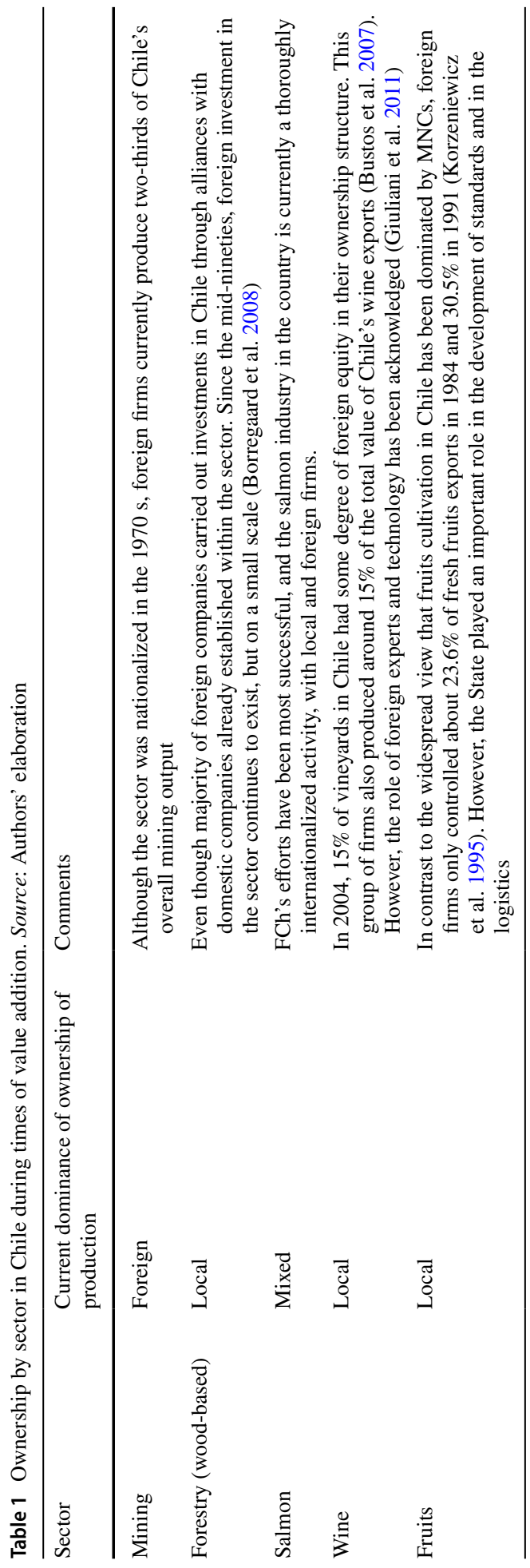


these market failures has had some impact on a selected group of suppliers (Iizuka et al. 2020; Navarro 2018). ${ }^{12}$ Regardless the design and effectiveness of this program, the size of the interventions is not commensurate with the magnitude of the challenge it is seeking to address.

\subsection{Summary discussion of Chile}

The lessons from the Chilean case can be summarized as follows. First, in addition to market forces, many industrial policy interventions have fostered the creation and strengthening of new non-traditional sectors based on natural resources. Importantly, this is very different from the usual narrative that paints Chile's success as entirely due to liberalization and open markets.

Second, Chile has achieved upgrading into high value-added activities within commodity sectors (a totally new activity, such as salmon harvesting, and a well-established one, like fresh fruit), without relying on foreign-dominated global value chains, but by instead transferring and adapting technology to local conditions. Except for mining, substantial local ownership has emerged in successful resource sectors, even though to a varying degree (Table 1).

Third, efforts for value addition in the copper sector are still modest and most of the copper is exported as copper ore. This suggests that in the copper sector, Chile appears to be following the third "resource-rent maximization" pathway, with the high prices prevailing in the early $2000 \mathrm{~s}$ helping its way out of the MIT. Indeed, refering to our conceptual model in Fig. 2, Chile may be more a combination of pathways 2 and 3 (resource-based development and resource-rent maximization) rather than only one pathway.

Fourth, the sectoral stories also signal the importance of managing the local-foreign interface strategically, recognizing the positive contribution, as well as the limitation, of foreign direct investment (FDI), especially to access foreign knowledge and technology.

In the next section, we will see if this synthesis also applies to Malaysia.

\section{Industrial policy and upgrading in key sectors of Malaysia}

In contrast to Chile, Malaysia is often perceived to have caught up by diversifying away from commodities. However, its manufacturing has not achieved much success as discussed in Sect. 2.2. Instead, Malaysia has recently been obtaining some success in promoting exports in commodity sectors that have existed since independence (Chang 2007). ${ }^{13}$ This differs from Chile's resource-based development, which featured efforts to acquire capabilities in 'new' commodity sectors (such as salmon farming and radiata pine production).

\subsection{Industrial upgrading in resource sectors: petroleum, palm oil and rubber}

Resource-based manufacturing in Malaysia consists of the production and export of rubber-based products (such as latex goods and tyres), petroleum-based products (such as

\footnotetext{
12 The estimated pool of mining suppliers in the country ranges between 4500 to 6000 (Comisión Nacional de Productividad 2017). 31 of the 75 suppliers participating in the program had applied for patents before participating in the program (Navarro 2018) — a much higher percentage than the average Chilean firm.

13 Neither rubber nor palm oil are native to Malaysia, as they were brought by the colonial administration.
} 
petrochemicals, plastics, fuel, synthetic rubber, etc.) and palm oil-based products (such as kernel cake and oleochemicals). These sectors together have become the leading engine of export growth, which is notably the result of government support through fiscal and R\&D incentives, and quality control services (Lebdioui 2019b). In these sectors, the role of a state-owned firm, such as Petronas in petroleum sector, or of other public agencies, has been critical, such as Malaysian Rubber Board (MRB) in rubber, FELDA (Federal Land Development Agency) and the Malaysian Palm Oil Board (MPOB). What follows is an elaboration of each sector.

The petroleum sector of Malaysia was initially dominated by multinational oil companies which remained the main providers of upstream technology in the early periods of resource exploitation, especially given the context of Malaysia's technology-demanding offshore and deep-water fields. ${ }^{14}$ To overcome such situation, the government of Malaysia established a state-owned enterprise, Petronas, in 1974, which became possible by proclamation of the Petroleum Development Act (PDA), and the associated Production-Sharing Contracts (PSC). The objective of the PDA was to gain greater national control over petroleum resources, to provide affordable petroleum resources to the local market to form the basis for capital and energy-intensive industries, and to encourage production linkages in both upstream and downstream activities (Nordas et al. 2003). Petronas, the state-owned oil corporation, has also gradually developed capabilities and upgraded into higher value activities.

The government also initiated a holistic approach in industrial policy combining local content requirements, tax incentives, skills transfer (through technical and specialized universities), state-led investments and opportunities for learning (Lebdioui 2019a). These tools have been successful in enhancing the industrial capabilities of local suppliers by allowing local firms to benefit from more stable intra-industry relationships, exposure to best practices, quality standards, as well as marketing capabilities. This holistic approach led to the accumulation of the capabilities needed for knowledge intensive activities along the petroleum value chain.

Petronas was a key vehicle for such industrial policy drive as it ran a program like the Petronas Vendor Development Program to develop the capabilities of local suppliers. Petronas' partners are also required to pay Petronas an annual research contribution, the "Research Cess" in order to promote joint R\&D (PSC, Arts 9.1 and 9.2). Thus, growth of local companies followed that of Petronas, and 74\% of total value of contracts in upstream activities in the petroleum sector was granted to local companies by 1995 (Tordo and Anouti 2013). ${ }^{15}$ Given the key role in promoting production linkages through several initiatives, it is doubtful whether similar value addition results would have been achieved if international oil corporations had controlled the sector. Petronas itself has grown into a fully integrated international oil and gas company, which operates in over 30 countries. It is now among the list of the global Fortune 500 companies.

In both rubber and palm oil sector, the plantations were all foreign-owned in the early days of the colonial period, and there was no interest in increasing domestic valueadded. The largely European-controlled plantation companies preferred to export crude palm oil and did not see many gains in relocating their vegetable oil processing facilities

\footnotetext{
${ }_{14}$ For instance, Shell and Mitsubishi fully carried out the technical development, sales and marketing of Malaysia's first LNG plant (Nordas et. al 2003).

15 The Malaysian Plan does not, however, say how much of this was value added produced by locally owned firms, and how much was delivered by multinationals established in Malaysia (Nordas et al. 2003).
} 
in Malaysia. After the initial entry point into the foreign-dominated GVCs during colonial times, Malaysia broke up those foreign-led GVCs with the nationalization of domestic firms through a hostile takeover of three British palm oil and rubber plantation conglomerates listed in the London stock exchange by Malaysian public capital in 1981 (Oikawa 2016; Lebdioui 2019b). The interest in processing palm oil and natural rubber locally increased since then. In addition, in the rubber sector, a large difference in purchasing behavior can be noted between domestic and foreign firms. Foreign-owned firms have fewer forward and backward linkages with other manufacturers in Malaysia than domestically owned firms.

Interestingly, Malaysia's efforts to stimulate industrial upgrading were met with counter-attacks from the incumbent firms. For instance, Malaysia's export processed palm oil in the $1970 \mathrm{~s}$ were blocked by the European common market, which practiced tariff escalation to make sure that refining capacity would remain in Europe. In order to counter the EU import duty structure, the Malaysian government had initially decided to introduce an export duty on crude palm oil production. After further tariffs escalation in the EU in the $1990 \mathrm{~s}$ from about $100 \%$ in the $1970 \mathrm{~s}$ to more than $200 \%$ in the $1990 \mathrm{~s}$ (Gopal 2001), most market deals for Malaysian processed palm oil were signed through government-to-government partnerships under so-called barter arrangements. As a result of this barter trade that enabled to secure export markets, palm oil refining activities in Malaysia considerably increased and became the most competitive internationally within 10 years, achieving both economies of scale and scope. ${ }^{16}$ Such upgrading into exporting processed palm oil, rather than crude oil, would not have been possible if there was no change of ownership from foreign to local. Another important incentive for processing palm oil was the higher export taxes on crude oil and lower taxes for more processed oil, which made domestic prices of crude and processed oil deviate from the international market prices (Jomo and Rock 1998; Oikawa 2016).

Such upgrading in the palm oil sector has been backed by increased R\&D efforts led by the Malaysian Palm Oil Board (MPOB) ${ }^{17}$ which has been responsible since the late 1970 s for R\&D on all palm oil-related activities, starting with chemistry, quality, analytical techniques, transportation and handling of palm oil products, and later expanded towards R\&D in oleochemicals and processed palm kernel oil, following the recommendations of the Industrial Master Plans (Azhar 2009; Oikawa 2016). ${ }^{18}$ The financial support from the government for R\&D also targeted such products, ranging from oleo-chemical byproducts to environment-friendly cultivation and manufacturing methods. Such R\&D effort enabled firms to increase value added in existing products, as well as enabled the introduction of new products in markets (such as biodiesel, specialty fats and vitamin A) (Rasiah and Shahrin 2006). Government-funded R\&D, through MPOB, has also been conducted to stimulate innovation towards oil palm biomass, but it is too soon to assess whether those efforts will be fruitful. Indeed, while considerable ground has been covered to pursue value addition towards processed palm oil and oleochemicals, further efforts are required to

\footnotetext{
${ }^{16}$ In the case of Palm oil, Malaysia had specialized in one type of oil (palm oil), while Europeans had no scope nor scale as they were processing different types of oils, according to the season (Jomo Kwame Sundaram, personal communication, cited in Lebdioui 2019b).

17 MPOB is the result of the merger between the former PORLA (Palm Oil Registration and Licensing Authority) and PORIM (Palm Oil Research Institute of Malaysia) (Oikawa 2016).

18 Research grants in the palm oil industry accounted to around USD 565 million between 2000 and 2010 (Rasiah 2015).
} 
move towards highly sophisticated value-added palm oil-based products (such as biodiesel and specialty oleochemicals).

In the rubber sector, the Malaysian Rubber Board (MRB) has become the world leading authority in rubber-related $R \& D$, and has accumulated expertise across the whole rubber value chain, from cultivation, plantation management to rubber manufacturing techniques and rubber products marketing (Goldthorpe 2015). Several Malaysian-owned firms have become world-leading producers for rubber-based products such as latex gloves and prophylactic goods, in highly competitive markets with low cost producers (i.e. China and India) and other natural rubber producing countries (i.e. Thailand and Vietnam).

\subsection{Mixed success in the leading manufacturing sectors: E\&E and automotive}

In contrast to the successful upgrading in the three resource-based sectors reviewed above, the E\&E industry in Malaysia reveals mixed success, despite its dominance in the export basket. This can be attributed to a combination of a lack of explicit industrial policy and of a critical mass of locally-owned firms vis-à-vis continuing dominance of MNCs in the sector. Again, dominance of MNCs implies less room for state intervention and less interests in building local capabilities, local suppliers and local linkages.

In the E\&E sector, the government adopted a rather 'minimalist' approach, mostly providing basic infrastructure and government services, and promoting FDI by offering tax incentives and low wages (Rasiah 2017). The initial outcome was the successful growth of low value-added labor-intensive FDI-led manufacturing. However, such strategy was not sustainable in the long-term because Malaysia also faced rising wage rates, while other neighbouring countries were offering lower wages to attract FDI. As a result, the E\&E sector in Malaysia was not innovative enough to compete against high-wage innovators from the top, and, at the same time, their wages were already too high to compete against low-wage manufacturers. This is the typical symptom of the middle-income trap (World Bank 2012), and some studies already discussed such possibility for Malaysia (Cherif and Hasanov 2019a; Rasiah 2006; Yusuf and Nabeshima 2009).

Such situation is partly due to the fact that there was no explicit industrial policy aiming at developing indigenous technologies in the E\&E sector up until the $2000 \mathrm{~s}$. The initial objective underlying the promotion of the E\&E sector was indeed employment generation. It was only since the $2000 \mathrm{~s}$ that more efforts have been provided through the industrial master plans, tax incentives, R\&D grants and state investments, to move domestic firms towards more value-added activities. For instance, in the semiconductor segment, targeted investments in high-end activities, such as chip design, wafer fabrication, and supportive R\&D took place since 2005 (Rasiah 2017). Despite recent attempts to increase local content and manufacturing value added, the results, although tangible, remained limited (Siew Yean 2015; Lebdioui 2019c). Malaysia's shares of global high-tech exports have decreased in the past decade, and Malaysia is losing its labour cost advantage to neighbouring countries (e.g. Vietnam). In the meantime, technology diffusion and domestic linkages remained constrained by the lack of technology transfer by MNCs in Malaysia (Cherif and Hasanov 2019a; Raj-Reichert 2019).

The automotive sector of Malaysia is a completely different story, as it was subject to aggressive interventions, with infant industry protection, high tariffs and national ownership. However, it has failed to grow into an internationally competitive sector. Such failure has to do with the presence of only carrots and the absence of sticks, which made industrial policy highly asymmetric. No sticks implied that two national brand carmakers (Proton 
and Perodua) were not to compete with each other even in the domestic market, but to play in different segments (Tai and Ku 2013; Athukorala 2017). Neither were they pushed to export to the world market.

While there were some initiatives to promote local content and suppliers (Athukorala 2017; Wad and Govindaraju 2011), the two flagship car makers did not pursue technological development, such as localization of production of engines and transmission, but kept using foreign-imported ones. In this light, they differed critically from the examples of Hyundai in South Korea or Geely in China, both of which pursued localization of key intermediate capital goods such as engines and transmissions (Lee and Lim 2001; Lee et al. 2016). Thus, the two flagship national champions failed to take off, as shown by the very low RCA and trade deficits of transport sector (see "Appendix" Fig. 9). The two national makers thus faced no discipline from the international market to upgrade their innovation capabilities, and the limited size of domestic markets prevented them from achieving economies of scale. Instead, these firms should have devoted the financial resources gained from quasi-monopoly profits to upgrading their technological capabilities to produce their own engines, which did not happen given the context.

While we argue that the industrial policy in automotive can be considered as illdesigned and lacking the incentives to induce to localize engines and transmission, one qualification is in order. The technological barriers to entry are much higher in the automobile engines or transmission than in palm oil processing. The latter is capital intensive, but uses mature technologies that are easily available in the market. Furthermore, Malaysia's natural environment clearly contributes to its competitive advantage in palm oil plantations (Oikawa 2016).

\subsection{Summary discussion of Malaysia}

The discussion in the preceding sub-sections suggests a couple of lessons. First, there are common elements of success in the three resource-intensive sectors (rubber, petroleum, palm oil): a similar combination of industrial policy and eventual growth of locally-controlled firms. In the Malaysian case, the role of local ownership is very explicit for all three sectors (Table 2). Second, the experience of the automotive sector suggests that a strong export-orientation should be added as a requirement for success.

\section{Concluding remarks}

Several findings emanate from our study. Firstly, Chile and Malaysia are on the path of escaping the middle-income trap in terms of their income level compared to the USA. Secondly, their leading export engines are not only traditional sectors, such as E\&E in Malaysia or mining in Chile, but also 'new' resource-based sectors, such as such as petroleum, rubber and palm oil in Malaysia, and salmon, fruits, wine and forestry in Chile. Thirdly, the sustained growth of these export sectors has been possible not through free-markets alone, but due to industrial policy fostering the build-up and accumulation of productive and innovation capabilities. In both Chile and Malaysia, industrial policies have offered R\&D support, fiscal incentives, export assistance, and quality control to foster industrial upgrading towards higher value products and activities. The cases analyzed here show clearly that such upgrading requires government interventions. In particular, given the possibility of a different kind of resource curse - a price boom reinforcing the prevailing export of crude 


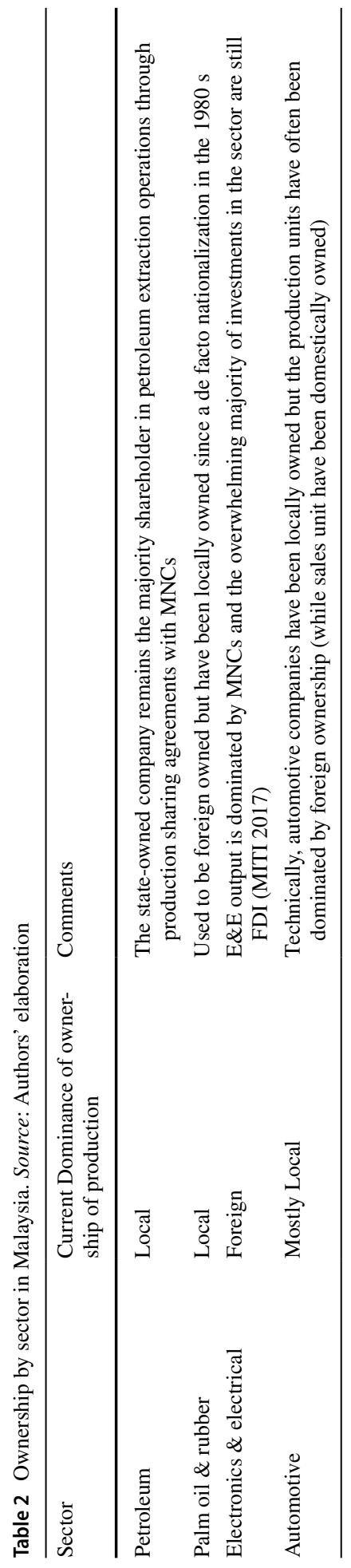


or unprocessed commodities (e.g. crude palm oil) but discouraging the desired transition to export of processed commodities (Sato 2016)—, 'getting prices wrong' by taxes, subsidies or regulation may be necessary.

Fourthly, we also find that the eventual emergence of locally-controlled firms is an important aspect of this long-term success, although the sources of initial learning importantly included foreign actors and FDI. Indeed, as clearly shown by the case of palm oil and rubber in Malaysia, the local control of raw materials enabled these countries to gain leverage to promote local value addition. This is consistent with the early insights by Amsden (1989) that foreign investments and MNCs can be important channels to access foreign knowledge, but tend to interfere with the eventual growth of indigenous technological capabilities. Overall, the Malaysian and Chilean experiences are also consistent with the nonlinear pattern of the GVC participation in Lee et al. (2018), which emphasizes the transient separation from GVC at the middle-income stages, so as to increase domestic valueadded and to develop technological capabilities.

Finally, because the cases of Chile and Malaysia show the possibility of escaping the middle-income trap not through manufacturing but through natural resource-based sectors, a key contribution of this study is to reveal that there can be alternative pathways for countries to escape the middle-income trap. The first is based on the idea of catching up by developing technological capabilities in short cycle technology manufacturing or service sectors, with low-entry barrier and analysed in Lee (2013). While another escape would be based on high commodity rents per capita in country such as Qatar, Kuwait, UAE, or Equatorial Guinea, it might not be really sustainable in the long term as it is highly vulnerable to commodity price fluctuations. Thus, an alternative (also resource-based) pathway out of the MIT is a gradual way to exercise consistent industrial policy to promote linkages and technological capabilities around resource-based industries, rather than resource rents alone. Our contribution is therefore the analysis of this alternative route with the example of the resource-based sectors in Chile and Malaysia, which appear to have constituted the low-entry barrier industries proposed by Lee (2013). This is somewhat different from the early arguments by Latin American scholars (Perez 2010) that Latin America should utilize resource-based development to leapfrog into emerging technologies. If our argument proves true, the Chilean and Malaysian cases suggest that the resource sectors could be the ultimate leading sectors generating intra-sectoral diversification and deepening in valuechains, and not just transitional sectors leading diversification into manufacturing sectors.

Open Access This article is licensed under a Creative Commons Attribution 4.0 International License, which permits use, sharing, adaptation, distribution and reproduction in any medium or format, as long as you give appropriate credit to the original author(s) and the source, provide a link to the Creative Commons licence, and indicate if changes were made. The images or other third party material in this article are included in the article's Creative Commons licence, unless indicated otherwise in a credit line to the material. If material is not included in the article's Creative Commons licence and your intended use is not permitted by statutory regulation or exceeds the permitted use, you will need to obtain permission directly from the copyright holder. To view a copy of this licence, visit http://creativecommons.org/licenses/by/4.0/.

\section{Appendix}

See Figs. 8 and 9. 


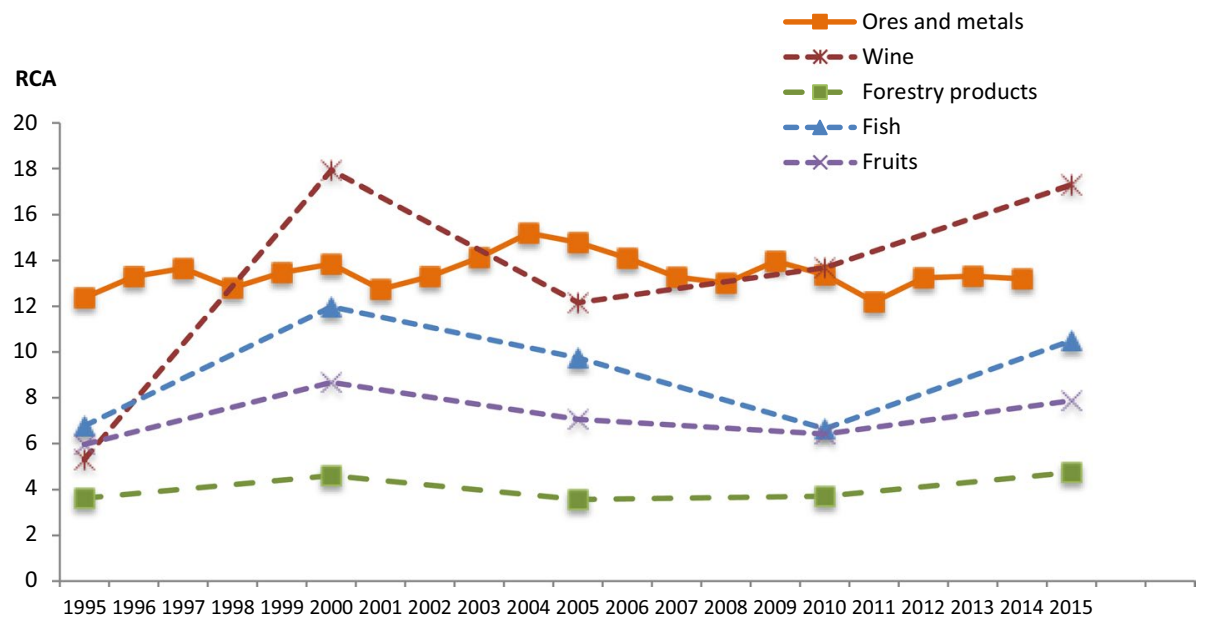

Fig. 8 Chile's RCA by sector (1995-2015). Source: Authors' compilation based on data provided by UN Comtrade Database, WITS and the Observatory of Economic Complexity. Notes: Forestry products here correspond to the sum of products with the following SITC3 codes: 63, 64, 24 and 25. Wood-based sector and forestry sector are used interchangeably in this paper

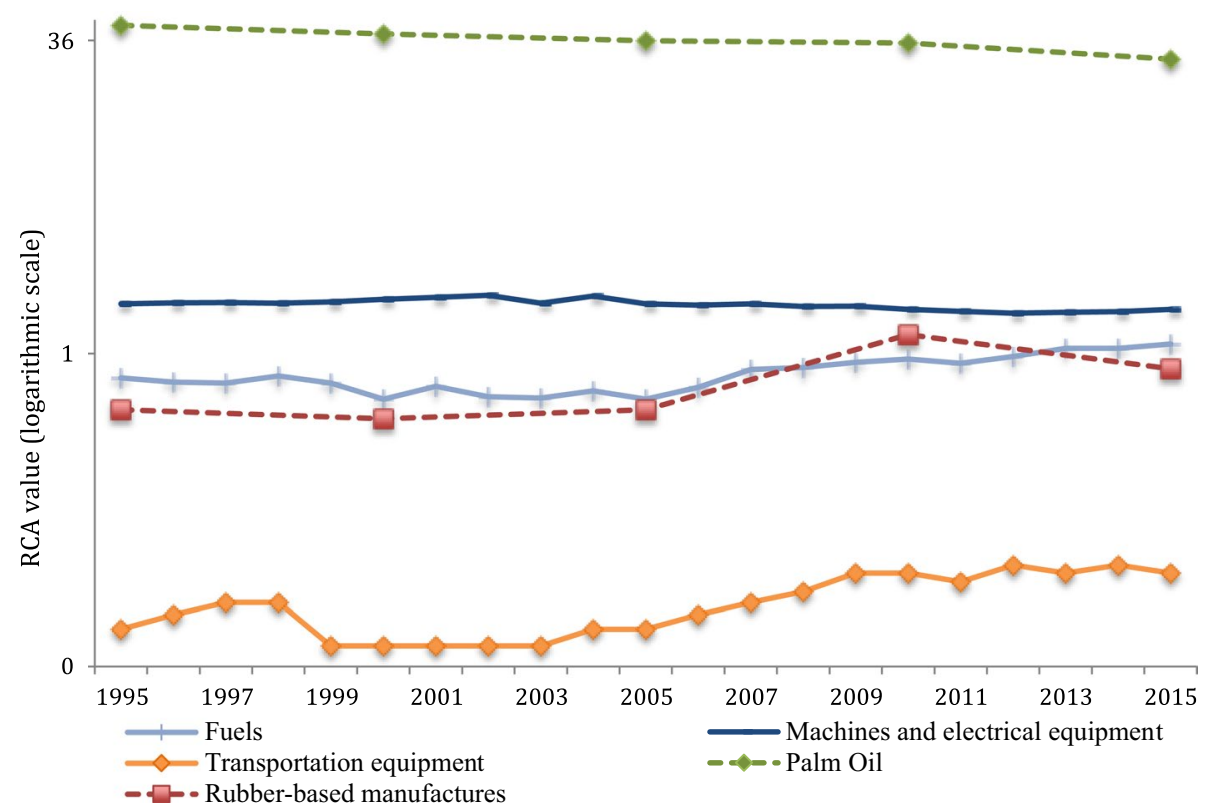

Fig. 9 Malaysia's RCA by sector (1995-2015). Source: Authors' compilation based on data provided by UN Comtrade Database, WITS and the Observatory of Economic Complexity 


\section{References}

Agosín, M, \& Bravo-Ortega C. (2009). The Emergence of New Successful Export Activities in Latin America: The Case of Chile. Inter-American Development Bank, Washington D.C, February 2009. https://publications.iadb.org/handle/11319/3716.

Agosin, M, Larraín, C. \& Grau, N. (2010). Industrial Policy in Chile" Department of Research and Chief Economist. IDB-WP-170. IDB WORKING PAPER SERIES No. Inter-American Development Bank. December 2010

Aiyar, S., Duval, R., Puy, D., Wu, Y., Zhang, L., (2013). Growth Slowdowns and the Middle-Income Trap. IMF Working Paper. No. 13/71. Washington, DC.

Amsden, A. H. (1989). Asia next giant-how korea competes in the world-economy. Technology Review, 92(4), 46-53.

Amsden, A. H., \& Chu, W.-W. (2003). Beyond late development: Taiwan's upgrading policies. New York: The MIT Press.

Athukorala, P. C. (2017). Industrialisation through state-Mnc partnership: Lessons from Malaysia's national car project. Malaysian Journal of Economic Studies, 51, 113-126.

Azhar, A. A. (2009). Presentation of Malaysian palm oil industry. Presented at the skills and knowledge for sustainable development in Africa: Lessons from Singapore and other Asian countries, 21-27 June, Singapore, retrieved from: https://siteresources.worldbank.org/EDUCATION/Resources/2782001121 703274255/1439264-1242337549970/Malaysian_Palm_Oil_Industry.pdf.

Barro, R. J. (2000). One pinochet legacy that deserves to live, businessweek, p. 22.

Benavente, J. M., \& Goya, D. (2012). The Economics of IP in the context of a Middle Income Country. Economia y negocios, Depto de Economia, SDT, 350.

Björk, I. (2005). Spillover effects of FDI in the manufacturing sector in Chile. Master's Thesis, Lund University.

Borregaard, N., Dufey, A., \& Winchester, L. (2008). Effects of foreign investment versus domestic investment on the forestry sector in Latin America (Chile and Brazil)-Demystifying FDI effects related to the Environment. Discussion Paper Number 15. Working Group on Development and Environment in the Americas. https://ase.tufts.edu/gdae/Pubs/rp/DP15Borregaard_Dufey_Winch esterApr08.pdf

Bravo-Ortega, C. \& Muñoz, L. (2015). Knowledge intensive mining services in Chile: Challenges and opportunities for future development. Inter-Amercian Development Bank, Discussion paper IDBDP-418. Washington D.C.: InterAmercian Development Bank.

Bustos, J., Pena Torres, J., \& Willington, M. (2007). Propiedad extranjera y especialización productiva en la industria del vino en Chile. https://fen.uahurtado.cl/wp-content/uploads/2010/07/inv184.pdf

CEPAL. (1986). El Desarrollo frutícola y forestal en Chile y sus derivaciones sociales, Estudios e Informes de la CEPAL n.57, Santiago, Chile: United Nations.

Chang, H.-J. (2007). State-owned enterprise reform. New York: United Nations Department of Economic and Social Affairs. United Nations DESA National Development Strategies Policy Notes.

Cherif, R., \& Hasanov, F. (2019a). The leap of the tiger: escaping the middle-income trap to the technological frontier. Glob Policy, 10, 497-511. https://doi.org/10.1111/1758-5899.12695.

Cherif, R., \& Hasanov, F. (2019b). The return of the policy that shall not be named: Principles of industrial policy. Working Paper No. 19/74, International Monetary Fund.

Cherif, R., Hasanov, F., \& Zhu, M. (2016). Breaking the oil spell: The Gulf Falcons' path to diversification. Washington, D.C.: International Monetary Fund.

Comisión Nacional de Productividad. (2017). Productividad en la Gran Minería Del Cobre en Chile, vol. 1, pp. $1-445$.

Confraria, H., \& Vargas, F. (2019). Scientific systems in Latin America: Performance, networks, and collaborations with industry. The Journal of Technology Transfer, 44(3), 874-915.

CORFO. (2019). Instituto Tecnologico de energia solar. www.corfo.cl/sites/cpp/convocatorias/instituto_ tecnologico_de_energia_solar.

Eichengreen, B., D. Park, \& K. Shin. (2013). Growth Slowdowns redux: New evidence on the middleincome trap. National Bureau of Economic Research.

Eichengreen, B., Park, D., \& Shin, K. (2012). When fast-growing economies slow down: International evidence and implications for China. Asian Economic Papers, 11(1), 42-87.

Gill, I. S., \& Kharas, H. (2007). An East Asian renaissance: Ideas for economic growth. Washington, D.C.: World Bank.

Giuliani, E., Morrison, A., \& Rabellotti, R. (Eds.). (2011). Innovation and technological catch up: The Changing geography of wine production. Cheltenham: Edward Elgar. 
Goldthorpe, C. C. (2015). Rubber manufacturing in Malaysia: Resource-based Industrialization in Practice. Singapore: NUS PRESS.

Gopal, J. (2001). The development of Malaysia's palm oil refining industry: Obstacles, policy and performance. PhD. Thesis submitted to Imperial College, London.

Griffith-Jones, S., Luz Martínez, S. M., \& Petersen, J. (2018). The role of CORFO in Chile's development: Achievements and challenges. In S. Griffith-Jones \& J. A. Ocampo (Eds.), The future of national development banks. New York: Oxford University Press.

Guerrieri, P., Iammarino, S., \& Pietrobelli, C. (2001). The global challenge to industrial districts: SMEs in Italy and Taiwan. Cheltenham: Edward ELGAR.

Gwynne, R. N. (2012). Globalising economic spaces, uneven development and regional challenges. Urbani Izziv, 23(supplement 2), S36-S48.

Han, Xuehui, \& Wei, Shang-Jin. (2017). Re-examining the middle-income trap hypothesis (MITH): What to reject and what to revive? Journal of International Money and Finance, 73, 41-61.

Hosono, A. (2010). Nambei Chili wo sake yushutsu taikoku ni kaeta Nihonjintachi (The Japanese who transformed Chile into a major salmon exporter). Tokyo: Daiyamondo-sha.

Hosono, A. (2016). Genesis of Chilean salmon farming. In A. Hosono, M. Iizuka, \& J. Katz (Eds.), Chile's salmon industry: Policy challenges in managing public goods (pp. 21-44). Berlin: Springer.

Iizuka, M, \& Gebreeyesus, M. (2012). A systemic perspective in understanding the successful emergence of non-traditional exports: Two cases from Africa and Latin America, UNU-MERIT Working Papers 052, United Nations University, Maastricht

International Monetary Fund. (2017). IMF datasets. https://data.imf.org.

Iizuka, M., Pietrobelli, C., \& Vargas, F. (2020). The potential for innovation in mining value chains evidence from latin America. In A. Daly, D. Humphreys, J. Raffo, \& G. Valacchi (Eds.), Innovation and mining. Cambridge: Cambridge University Press.

Iizuka, M., Roje, P., \& Vera, V. (2016). The development of Salmon aquaculture in Chile into an internationally competitive industry: 1985-2007. In A. Hosono, M. Iizuka, \& J. Katz (Eds.), Chile's Salmon industry: Policy challenges in managing public goods. New york: JICA Research Institute.

Im, F. G. \& Rosenblatt, D. (2013). Middle-income traps: A conceptual and empirical survey. World Bank Policy Research Working Paper No. 6594.

Ito, T. (2017). Growth convergence and the middle-income trap. Asian Development Review, 34(1), $1-27$.

Jomo, K. S., \& Rock, M. (1998). Economic diversification and primary commodity processing in the second-tier South-East Asian newly industrializing countries. UNCTAD Discussion Paper, no. 136. Geneva: United Nations Conference on Trade and Development.

Kim, L. (1997). Imitation to innovation: The dynamics of Korea's technological learning. Boston: Harvard Business School Press.

Korzeniewicz, R. P., Goldfrank, W., \& Korzeniewicz, M. E. (1995). Vines and wines in the world economy. In P. McMichael (Ed.), Food and Agrarian orders in the world-economy (pp. 113-138). Westport: Greenwood Publishing Group.

Kunc, M. (2007). A survey of managerial practices in the Chilean wine industry. Journal of Wine Research, 18, 113-119.

Kunc, M. \& Bas, TG. (2009). Innovation in the Chilean wine industry: The impact of foreign direct investments and entrepreneurship on competitiveness. American Association of Wine Economists Working Paper No. 46.

Lebdioui, A. (2019a). Local content in extractive industries: Evidence and lessons from Chile and Malaysia. Extractive industries and Society. https://doi.org/10.1016/j.exis.2019.05.001.

Lebdioui, A. (2019b). Economic diversification and development in resource-dependent economies: Lessons from Chile and Malaysia. PhD thesis. University of Cambridge.

Lebdioui, A. (2019c). Chile's export diversification since 1960: A free market miracle or mirage? Development and Change, 50(6), 1624-1663.

Lee, K. (2013). Schumpeterian analysis of economic catch-up: knowledge, path-creation, and the middle-income trap. Cambridge: Cambridge University Press.

Lee, K. (2019). The art of economic catch-up: Barriers, detours, and leapfrogging. Cambridge: Cambridge University Press.

Lee, K., Gao, X., \& Li, X. (2016). Industrial catch-up in China: A sectoral systems of innovation perspective. Cambridge Journal of Regions, Economy and Society, 10(1), 59-76.

Lee, K., \& Lim, C. (2001). Technological regimes, catching-up and leapfrogging: Findings from the Korean Industries. Research Policy, 30(3), 459-483. 
Lee, K., Szapiro, M., \& Mao, Z. (2018). From global value chains (GVC) to innovation systems for local value chains and knowledge creation. The European Journal of Development Research, 30(3), 424-441.

Lema, R., Pietrobelli, C., \& Rabellotti, R. (2019). Innovation in global value chains. In S. Ponte, G. Gereffi, \& G. Raj-Reichert (Eds.), Handbook on global value chains. Cheltenham: Edward Elgar.

Marin, A., \& Bell, M. (2006). Technology spillovers from foreign direct investment (FDI): The active role of MNC subsidiaries in Argentina in the 1990s. The Journal of Development Studies, 42(4), 678-697.

Meller P. \& Parodi P. (2017). Del Programa de Proveedores a La Innovación Abierta En Minería. Mimeo CIEPLAN.

Morrison, A., Pietrobelli, C., \& Rabellotti, R. (2008). Global value chains and technological capabilities: A framework to study learning and innovation in developing countries. Oxford Development Studies, 36(1), 39-58. https://doi.org/10.1080/13600810701848144.

Navarro, L. (2018). The world class supplier program for mining in Chile: Assessment and perspectives. Resources Policy, 58, 49-61.

Nordas, H., Vatne, E., \& Heum, P. (2003). The upstream petroleum industry and local industrial development: A comparative study. Bergen: Institute for Research in Economics and Business Administration.

OECD and World Bank. (2011). Revisión de Políticas Nacionales de Educación: Programa Becas Chile. Paris: OECD.

Oikawa, H. (2016). Resource-based industrialization of the Malaysian palm oil industry. In Y. Sato \& H. Sato (Eds.), Varieties and alternatives of catching-up (pp. 247-276). London: Palgrave Macmillan.

Perez, C. (2010). Technological dynamism and social inclusion in Latin America: A resource-based production development strategy. CEPAL Review $N^{o}$, 100, 121-141.

Pietrobelli C. (1993). El proceso de diversificación de exportaciones en Chile, Estudios e Informes de la CEPAL n.84, Santiago, Chile; United Nations.

Pietrobelli, C. (1998). Industry, competitiveness and technological capabilities in Chile. A new tiger from latin America?. London: Macmillan.

Pietrobelli, C., Marin, A., \& Olivari, J. (2018). Innovation in mining value chains: New evidence from Latin America. Resources Policy, 58, 1-10. https://doi.org/10.1016/j.resourpol.2018.05.010.

Raj-Reichert, G. (2019). Global value chains, contract manufacturers, and the middle-income trap: The electronics industry in Malaysia. Journal of Development Studies, 56(4), 698-716.

Ramanayake, S., \& Lee, K. (2019). Does openness lead to sustained economic growth? Export growth versus other variables as determinants of economic growth. Journal of the Asia-Pacific Economy, 17, 29.

Rasiah, R. (2006). Explaining Malaysia's export expansion in palm oil and related products. Chapter 5 in Technology, adaptation, and exports: How some developing countries got it right. Washington, D.C.: World Bank.

Rasiah, R. \& Chandran V. G. R. (2015). Malaysia. UNESCO Science Report: towards 2030. http://unesd oc.unesco.org/images/0023/002354/235406e.pdf.

Rasiah, R. (2017). The industrial policy experience of the electronics industry in Malaysia. In J. Page \& F. Tarp (Eds.), The practice of industrial policy: government-business coordination in Africa and East Asia. Oxford: Oxford University Press.

Rasiah, R., \& Shahrin, A. (2006). Development of Palm Oil and Related Products in Malaysia and Indonesia. Kuala Lumpur: University of Malaysia.

Rodrik, D. (2006). Goodbye Washington consensus hello Washington confusion? A review of the World Bank's Economic Growth in the 1990 s: Learning from a decade of reform. Journal of Economic Literature, 44(4), 973-987.

Rossi, I. (1995). "Desarrollo y Competitividad del Sector Forestal-Maderero" ["Development and Competitiveness in the Forestry-wood Sector"]. In P. Meller \& R. Saez (Eds.), 'Auge Exportador Chileno: Lecciones y Desaf'los Futuros [Chile's Export Boom: Lessons and Future Challenges] (pp. 109-135). Santiago: Dolmen and CIEPLAN.

Sato, Y. (2016). Curse or opportunity? A model of industrial development for natural resource-rich countries on the basis of Southeast Asian Experiences. In Y. Sato \& H. Sato (Eds.), Varieties and alternatives of catching-up. London: Palgrave Macmillan.

Siew Yean, T. (2015). Diversification and industrial policies in Malaysia. In J. Felipe (Ed.), Development and modern industrial policy in practice. Cheltenham: Edward Edgar Publishing.

Stiglitz, J. (2002). Globalization and its Discontents. New York: W. W Norton \& Company.

Stubrin, L. (2018). Innovation, learning and competence building in the mining industry The case of knowledge intensive mining suppliers (KIMS) in Chile. Resources Policy, 58, 62-70.

Tai, W.-P., \& Ku, S. (2013). State and industrial policy: Comparative political economic analysis of automotive industrial policies in Malaysia and Thailand. Journal of ASEAN Studies, 1(1), 52-82. 
Tordo, S., \& Anouti, Y. (2013). Local content in the oil and gas sector: Case studies. Washington, D.C.: World Bank.

Trumbull, R. (1982). World's richest little isle. New York Times. March 7. https://www.nytim es.com/1982/03/07/magazine/world-s-richest-little-isle.html

UN Comtrade. (2019). International trade statistics database. Retrieved May 13, 2019 from https://comtr ade.un.org/.

Urzúa, O., Wood A., Iizuka M., Vargas F., \& Baumann J. (2017). Discovering new public-private partnerships for productive and technological development in emerging mining countries, Vol. 5. Working Document.

Valenzuela, A., \& Dammert, L. (2006). "A Left Turn” in Latin America? Problems of success in Chile. Journal of Democracy, 17(4), 65-79.

Wad, P., \& Govindaraju, V. G. R. C. (2011). Automotive industry in Malaysia: An assessment of its development. International Journal of Automotive Technology and Management, 11(2), 152-171.

Williamson, J. (1990)."What Washington Means by Policy Reform. Chapter 2 in Latin American Adjustment: How Much Has Happened? Peterson Institute for International Economics.

World Bank. (2010). Exploring the Middle-Income-Trap. Washington, D.C.: World Bank.

World Bank. (2012). China 2030: Building a modern, harmonious, and creative high-income society. Washington, D.C.: World Bank.

World Bank. (2018). World development indicators. Retrieved May 23, 2018 from https://data.worldbank. org.

Yusuf, S. \& Nabeshima, K. (2009). Can Malaysia escape middle income trap? A strategy for Penang. Policy Research Working Paper 4971, Washington, DC: The World Bank.

Publisher's Note Springer Nature remains neutral with regard to jurisdictional claims in published maps and institutional affiliations.

\section{Affiliations}

\section{Amir Lebdioui $^{1}$ (D) $\cdot$ Keun Lee $^{2,3} \cdot$ Carlo Pietrobelli $^{4}$}

Keun Lee

kenneth@snu.ac.kr

Carlo Pietrobelli

carlo.pietrobelli@uniroma3.it

1 London School of Economics and Political Science, London, UK

2 Seoul National University, Seoul, Korea

3 Institute for Statistical Studies and Economics of Knowledge, National Research University Higher School of Economics (HSE), Moscow, Russia

4 University Roma Tre and UNU-MERIT, Rome, Italy 